\title{
The MBA: "A Master's Degree a Mile Deep and an Inch Wide": A Reflection on MBA Curricula in South African Business Schools
}

\author{
Mankolo Lethoko \\ University of Limpopo, Turfloop Graduate School of Leadership, Webster Street, \\ Edupark, Fauna Park, PO Box 759,Polokwane 0787, Republic of South Africa \\ Email address: mankolo.lethoko@ul.ac.za \\ Oliver Mtapuri* \\ University of Limpopo, Turfloop Graduate School of Leadership, Webster Street, \\ Edupark, Fauna Park, PO Box 759,Polokwane 0787, Republic of South Africa \\ Email address: oliver.mtapuri@ul.ac.za
}

Doi:10.5901/mjss.2014.v5n23p527

\section{Abstract}

This article investigates the curricula of MBA programmes in South Africa business schools. It is based on a study in which telephonic interviews and content on the business schools' curricula was analysed using content analysis. From this, there are 14 common modules in South African business schools. The knowledge and skills offered could be necessary but not sufficient for managerial roles given a deficiency in interpersonal skills and dispositions in the menu of current offerings at business schools. This article argues that the occupation of managerial roles either at junior or senior level is situational and circumstantial or may not be directly linked to the acquisition of an MBA. Issues of the environment and entrepreneurship are critical for the development of countries; however, they appear on the sidelines as an afterthought among the current offerings albeit topical and contemporary in current circumstances. This article recommends that business schools must continuously consult with stakeholders - current students, alumni, employers and others in order for their programmes to remain relevant in the market and in practice.

Keywords: MBA, business schools, curriculum, core modules, electives

\section{Introduction}

MBA studies are growing in popularity all over the world. Originally established in the United States of America, they were adopted in Europe in the 1940s and in South Africa in the 1950s. There is also a continuous increase in students wishing to study for an MBA, and as such more and more MBA graduates enter the job market. Literature abounds of perceptions in which MBA holders believe the qualification is a passport into managerial roles. However, there has also been literature and studies conducted to the contrary. These are some of the negative rumblings associated with the MBA qualification worldwide, for example, Louw et al., 'MBA education in South Africa has become largely irrelevant to the needs of business practice in a rapidly changing business environment (Louw, Bosch \& Venter, 2001: 23). Blass et al., argue that 'The MBA is a qualification plagued by market confusion as to what it actually represents and what its value is" (Blass \& Weight, 2005: 229). As for Crous et al., 'MBA is an expensive venture, taking up large amount of time for companies and families' (Crous \& Cooper, 2005: 56)'. While Gupta, Saunders \& Smith (2007: 306)' claim that 'An MBA graduate is an informed generalist with no specialist skills'. Bloedsoe and Oatsvall, (2009: 2) posit that 'MBA programmes train wrong people in the wrong ways with the wrong consequences. Bruce (2010: 40) claims that 'there is little evidence that mastery of knowledge acquired in business schools enhances peoples' careers, or that even attaining the MBA credential itself has much effect on graduates' salaries and career attainment'.

These perceptions reflect the contestations around the MBA programme in terms of relevance, focus, worth and value to the individual, the market and society in general. It is against this backdrop that this article investigates the content of curriculum offered by twelve public higher education institutions in South Africa and four private business schools. As the Council of Higher Education (CHE) (2004) puts it 'the content (curriculum) of business education and the ways in which it is transmitted constitutes the crux of the existence of business schools'. This conceptual article, using content analysis, provides insights into content of the curricula offered by the major business schools surveyed in South 
Africa.

\section{Literature Review}

The MBA was introduced in the 1890s in the USA with Wharton and the University of Chicago presenting the first programme. In 1898, the University of Gallen was founded as one of the first business schools in Europe and with the turn of the 20 th century, Europeans developed Centres of Excellence in business such as at the Universities of London and Manchester (Crous \& Cooper, 2005). In South Africa, the history of MBA cannot be separated from the history of higher education and the apartheid legislation which had a determining role on the range of degrees and modules those institutions could offer as well as the students they could cater for (Council on Higher Education, 2004). Therefore the development of MBA degrees in South Africa started first in the historically white universities (both English and Afrikaans speaking). Then the historically black universities followed later. Up to the 1990s, there were only seven business schools in South Africa, but in 2002, there were 18 public higher education institutions (13 universities and five technikons) and nine private providers (five local and four transnational). These institutions offered 37 different programmes in total (CHE, 2004).

South Africa has 20 business schools accredited to offer MBA degrees (Council on Higher Education, 2007). This shows a massive expansion of MBA programmes. As Blass \& Weight (2005: 229) argue 'the last ten years have seen a massive expansion of MBA provision around the world with virtually every university business school having one and some having more than one'. In addition, Nance \& White (2012) also point out that the demand is vast for MBA qualifications as a consequence of the above average salaries paid to MBA graduates. These views partly confirm the relevance of an MBA qualification in business.

\subsection{Red warning lights flashing: the relevance of MBA curricula}

Various authors have pointed out that the proliferation of MBA degrees worldwide has caused concern about the appropriateness and the quality of the programmes offered (Tucker, 1995; Byrne, 1997; Beezhold, 1998; Hugo, 1998, Louw et al 2002; Boyatzis \& Renio, 2007; Wood \& Gordon, 2009, Nance \& White, 2012). In particular, there have been concerns leveled at the curriculum that is being taught in MBA programmes. Some of the criticisms include Slater \& Dixon-Fowler, (2010) who argue that MBA programmes are not relevant to those in practice.

Boyatzis \& Renio, (2007) criticize the MBA for not adequately developing the interpersonal skills required for leadership and effective management. This implies that it is imperative to continuously evaluate the modules and their content in light of what practicing managers value as well assess whether or not the programmes are responding to the needs of the market.

Some argue that an MBA is masters degree in nothing, whilst others feel that it is irrelevant and not really necessary in their fields of expertise. Illusions about the MBA degree have crumbled. MBAs are no longer treated as Messiahs or crown princes (Crous \& Cooper, 2005). 'The emerging gap between the needs of business environment and the provision of business schools has fuelled much of the criticism aimed at MBAs' (Blass \& Weight, 2004a).

It can be deduced that the value, relevance and sustainability of an MBA degree depends largely on the content of the curriculum on offer. Blass \& Weight (2004b) in their article entitled 'the MBA is dead - long live Masters of Business Leadership (MBL)' assert that in response to the criticism levels to MBA programmes, some business schools are recurriculating their programmes as well as their pedagogy including international visits to other business schools. While this may help pull the MBA into the $21^{\text {st }}$ century, it does not change the fact that the MBA is slipping from being an 'elite' business qualification to a mass graduate conversion programme which is seen as a necessary stepping stone to the ranks of junior rather than senior management.

The Council of Higher Education in South Africa last commissioned a National study of MBA programmes in 2002 in which the results were published in 2004. The article envisages answering the following questions: which modules form the core of MBA training in these business schools in South Africa? Which modules are most common electives in the curricula of these institutions? What is the relevance of both the core and electives to the present day South Africa in terms of its national priorities?

\section{Materials and Methods}

This article is based on a study of MBA Programmes at both private and public business schools in South Africa. Data was collected based on both telephonic interviews and information available on either the Business School's website or 
brochures. South Africa has 20 business schools, however for the purposes of this study, only 16 were utilised due to the availability of their curricula. This article utilised content analysis as its methodology which entailed an analysis of both core and elective modules offered per institution. Welman, Kruger \& Mitchell (2010: 221) define content analysis as 'a qualitative analysis of qualitative data. The basic technique involves counting the frequencies and sequencing of particular words, phrases and concepts in order to identify key words and themes'. Babbie \& Mouton (2013: 491) define the same concept as 'a research method which examines words or phrases within a wide range of texts (MBA curricula) including books, book chapters, essays, interviews, speeches and informal conversations. By examining the presence of repetition of certain words and phrases in these texts, a researcher is able to make inferences about the philosophical assumptions of a writer, a written piece, the audience to which the piece was written and even the culture and the time in which the text is embedded'.

According to CHE (2004), the first MBA degree in South Africa was offered by the University of Pretoria in 1949, whilst private providers on the other hand, started operating in South Africa from the year 2000. As such, South Africa has private institutions offering MBA degrees. However, the authors believe that the public institutions have a wealth of experience in terms of curricula development and if juxtaposed with private institutions will provide valuable insights into the curriculum offered by these institutions.

\section{Findings}

\subsection{Analysis of the core modules}

Using a cut off of 5 modules, the following modules were prominent: Marketing (invariably called Marketing Management; Sustainable Marketing; Marketing for Managers; Marketing and Customer Engagement; Services Marketing and Management and Strategic Marketing). All the business schools were teaching Marketing as a core subject being mentioned 16 times (100\%) (See Table 1 below).

Table 1: Most common core modules offered at business schools in South Africa $(n=16)$

\begin{tabular}{lcc}
\hline Subject & Number & $\%$ \\
\hline Marketing & 16 & 100 \\
Strategy & 16 & 100 \\
Financial Management & 16 & 100 \\
\hline Leadership & 15 & 93 \\
Human Resources & 14 & 87 \\
Research Methods & 14 & 87 \\
Managerial Economics & 13 & 81 \\
Operations Management & 12 & 75 \\
Management Accounting & 9 & 56 \\
Organisational Development and Transformation & 8 & 50 \\
Financial Accounting & 7 & 44 \\
Information Technology Management & 7 & 44 \\
Quantitative Methods & 6 & 38 \\
Business Ethics \& Corporate Governance & 6 & 38 \\
\hline
\end{tabular}

Strategy also called Corporate Strategy; Strategic Management; Strategic Management and Business Policy, Competitive Strategy; Managing Strategic Resources and Operations; Strategy and Company Analysis with a count of 16 (100\%) was being taught at all business schools. The same applies to Financial Management also called Finance; Managerial Finance; Finance and Responsible Investment; Business Finance; Managing Financial Resources; and Corporate Finance was being taught at all business schools.

Of interest is the fact that not all business schools were teaching Financial Accounting. The module with 7 counts (44\%) carried different nomenclatures such as Accounting for Decision Making; Integrated Accounting; and Accounting. Nine out of 16 business schools surveyed were teaching Management Accounting. Management Accounting was also not taught at all business schools with a count of $9(56 \%)$.

Most business schools (93\%) were also teaching Leadership with a count of 15. The nomenclatures were different varying from Leadership Development; Responsible Leadership; Leadership and Personal Development; Leadership, Emotional and Spiritual Intelligence; to Leadership Negotiation Strategy. 
Seven (44\%) out of 16 business schools were teaching Information Technology Management as a core subject. The module carried many tags such as Management Information Systems; Information and Communication Technology; Managing Information Technology and Information; and Systems Management. Six (38\%) out of the 16 business schools were teaching Quantitative Methods and Business Ethics and Corporate Governance as a core subject.

Marketing, Strategy and Financial Management are core modules at all business schools. This implies that all business school place a premium value on these modules because Marketing affects the bottom-line if it is not executed methodically and systematically. Strategy is the 'in-thing' and Financial Management can make or break a company as cash is the lifeblood of a firm going by what the discipline teaches. This could partly explain their importance or the premium placed on them besides the demands of the market.

\subsection{Analysis of the electives}

A cut-off of three electives was used to identify the most common elective modules offered by the business schools in South Africa. Entrepreneurship is the most common elective being offered by $10(63 \%)$ out of the 16 business schools. Entrepreneurship was named Entrepreneurial Process; Entrepreneurial Thinking; Entrepreneurial Management; Entrepreneurship and Innovation; Entrepreneurship and Small Business Management by the various business schools. This is followed by Information Technology with a count of $9(56 \%)$ of the 16 business schools. A quarter of the business schools were offering Public Sector Management and Environment Management, the former to appeal to civil servants and the latter is also considered as the 'in-thing'. This also applies to Project Management, an 'in-thing', which accounted for just about a third of the counts.

Table 2: Most common elective modules offered at business schools in South Africa

\begin{tabular}{lcc}
\hline Module & Number & $\%$ \\
\hline Entrepreneurship & 10 & 63 \\
\hline Information \& Knowledge Management & 9 & 56 \\
\hline Finance & 6 & 38 \\
\hline Project Management & 5 & 31 \\
\hline Public Sector Management & 4 & 25 \\
\hline Environment management & 4 & 25 \\
\hline Marketing Management & 3 & 19 \\
\hline Business \& Professional Ethics & 3 & 19 \\
Investment \& Portfolio Management & 3 & 19 \\
\hline
\end{tabular}

\subsection{Common subjects in core and electives}

Four modules, namely, Marketing, Information \& Knowledge Management, Finance and Business \& Portfolio Ethics were being offered as both Core and Elective modules. This is surprising because once it is a core module, a candidate should do the module.

\subsection{Number of Core and Electives offered per business school}

Table 3 below shows the number of core versus the electives being offered at 6 of the 16 business schools for an analysis of the offerings. This analysis has a bearing on programme content, programme organization, completion times and so forth.

Table 3: Number of Core and Electives offered per business school

\begin{tabular}{ccc}
\hline School & Core & Electives \\
\hline A & 16 & 7 \\
B & 16 & 4 \\
C & 13 & 17 \\
D & 13 & 7 \\
E & 12 & 6 \\
F & 11 & 8 \\
\hline
\end{tabular}


Business school $\mathrm{C}$ was offering 13 core modules and 17 electives. This suggests that the school was attempting to widen its catchment area by offering many electives. Business school $\mathrm{F}$ was offering 11 core modules in its programme while business school A was offering 16 core modules and 7 electives. This may suggest that candidates at business school A have a lot to learn given the numerous offerings however, it may well mean that their load is heavy and may impact on throughput and graduation rates. It may also speak to how the programme is organized and how the content is packaged.

\section{Discussion}

A curriculum which includes the 14 modules, namely, Marketing; Strategy; Financial Management; Leadership; Human Resources; Research Methods; Managerial Economics; Operations Management; Management Accounting; Organizational Development and Transformation; Financial Accounting; Information Technology Management; Quantitative Methods; and Business Ethics \& Corporate Governance would make a 'good sale' in the market given their apparent commonality/popularity in South African business schools.

Given these offerings, it could be argued that a candidate possessing these knowledge and skills could be a candidate for a managerial role. However, as to whether that role is at junior or senior management is situational and circumstantial.

Louw et al., argue that 'MBA education in South Africa has become largely irrelevant to the needs of business practice in a rapidly changing business environment (Louw, Bosch \& Venter, 2001: 23). This could be true because Financial Accounting, for instance, is not one of the prominent modules on the menu when it is in fact a critically scarce skill in the country. Environmental issues and entrepreneurship did not make it into the list when concerns of the environmental as well job creation are topical and contemporary in the country.

Blass et al., argue that 'The MBA is a qualification plagued by market confusion as to what it actually represents and what its value is" (Blass \& Weight, 2005: 229). This could also be true because of the inclusion of modules such as Public Sector Management as well as the offering of as many as 13 electives at one business school. This could be tied to Gupta, Saunders \& Smith (2007: 306)' argument that 'An MBA graduate is an informed generalist with no specialist skills'. The offerings reflect a generalist approach as specialization is rare in the current context.

As for Crous et al., 'MBA is an expensive venture, taking up large amount of time for companies and families (Crous \& Cooper, 2005: xx)'. The popularity of MBA programmes and the spread of business schools and concomitant expansion in student numbers herald huge investment by firms and students alike in terms of money and time in the acquisition of an MBA. Bloedsoe and Oatsvall, (2009: 3) posit that 'MBA programmes train wrong people in the wrong ways with the wrong consequences. Because the MBA appears generalist, it is open to lawyers, engineers, public servants (as in some cases), nurses, doctors, social workers and so forth. Whether or not these candidates are wrong and are trained in the wrong ways with wrong consequences is not a subject of this investigation. Bruce (2010: 41) claims that 'there is little evidence that mastery of knowledge acquired in business schools enhances peoples' careers, or that even attaining the MBA credential itself has much effect on graduates' salaries and career attainment'. This is also a subject of further investigation and in many is circumstantial and situational. Boyatzis \& Renio, (2007) criticize the MBA for not adequately developing the interpersonal skills required for leadership and effective management. Indeed, the fourteen modules given above exclude modules which develop interpersonal skills.

\section{Conclusion}

All the business schools were teaching Marketing, Financial Management and Strategy as core subjects suggesting that these modules are critical in the skills market and therefore much sought after. The sprouting of MBA programmes and business schools may herald the massification of the qualification. This may reduce its value in the market and necessitate a revision of the curricula for relevance. As such, it is pertinent that business schools must continuously consult with stakeholders in order for their programmes to remain relevant and of high quality in the market and in practice. The questions still remain: what is an MBA worth? Specifically, what skills, knowledge and dispositions must it provide? Must it remain general? Or must it specialize? Put differently, is it a Masters in everything or should it be Masters in something? If these issues are not addressed at programme level, the MBA may well remain a 'Masters in nothing' as others have claimed.

\section{References}

Babbie, E. \& Mouton, J. (2012). The practice of social research. Cape Town. Oxford Publishers. 
Beezehold, P. 1998. Look carefully before you buy. In Webster, E. (ED). Master of Business Administration: Business Day survey. Business Day, July 21, Vol. 21.

Blass, E. \& Weight, P. 2005a. MBA is dead - God save the MBA. On the Horizon, Vol. 13 Issue 4, pp. 229 - 240.

Blass, E. \& Weight, P. 2005b. The MBA is dead - part 2: long live the MBL! On the Horizon, Vol. 13 Issue 4, pp. 241 - 248.

Bledsoe, M. \& Oatsvall, R. 2009. Graduates: Perceptions on MBA. American Journal of Business Education. Vol. 2, No. 2 , pp. 1 - 5.

Bruce, G.D. 2010. Exploring the value of MBA degrees: experiences in full-time, part-time and Executive MBA programs. Journal of Education in Business. Vol. 85, issue 1, pp. $38-44$.

Boyatzis, R.E. \& Renio, A. 2007. Research article: The Impact of an MBA on managerial abilities. Journal of Management Development. Vol. 8, No. 5, pp. $66-77$.

Byrne, J.A. 1997. Business Week guide to best business schools. New York, McGraw-Hill.

Council on Higher Education (2007). Update on MBA Accreditation. Accessed from http://www.che.ac.za/media_and_publications/ accreditation-and-national-reviews/update-mba-accreditation on 23 July 2014.

Council on Higher Education. 2004. State of provision of the MBA in South Africa. Pretoria: Council of Higher Education.

Crous, T. \& Cooper, S. 2005. MBA: Does it add value of is it and expensive hype? Management Today, August 2005.

Gupta, P. B., Saunders, P. M. \& Smith, J. 2007. Traditional Master of Business Administration (MBA) Versus the MBA with specialization: A disconnection between what business schools offer and what employers seek. Journal of Education for business. July/August, 2007.

Hugo, W. 1998. Leadership makes a difference. MBA survey - winners' sponsored case study. Professional Management Review, September, Vol 16.

Louw, L., Bosch, J.K., Venter, D.J.L. 2001. Quality perceptions of MBA courses and required management competencies. Quality Assurance in Education. Vol. 9 No.2, pp.72-80.

Nance, D.R. \& White, D. W. 2012. Academic performance in MBA programs: Do prerequisites really matter? Journal of Education for business. Vol. 87, Issue 1, pp. $42-47$.

Slater, D. \& Dixon-Fowler, H. 2010. The future in the hands of MBAs: An examination of CEO MBA education and corporate environmental performance. Academy of Management Learning \& Education. Vol. 9, Issue 3, pp. 429 - 441.

Tucker, E. 1995. How business are shaping MBA courses. In Which Business qualification? The comprehensive guide to MBA and postgraduate courses throughout the whole world. London. The Edition publishing company.

Welman, C., Kruger, F. \& Mitchell, B. (2005). Research methodology. Cape Town. Oxford University Press.

Wood, B and Gordon, S. 2009. Design Linking MBA Learning and Leadership Coaching. International Coaching Psychology Review, Vol. 4, Issue 1, 87-104. 